\title{
CORRIGENDUM
}

\section{Genetic defects in the human glycome}

\section{Hudson H. Freeze}

Nature Reviews Genetics 7, 537-551 (July 2006), doi:10.1038/nrg 1894

Two key references were accidentally omitted from this review. The following reference should have been cited with regard to the finding that mutations in GALNT3 underlie hyperphosphataemic familial tumoral calcinosis:

- Topaz, O. et al. Mutations in GALNT3, encoding a protein involved in $\mathrm{O}$-linked glycosylation, cause familial tumoral calcinosis. Nature Genet. 36, 579-581 (2004).

In addition, the original discovery of mutations in FGF23 in hyperphosphataemic familial tumoral calcinosis should have been credited to the following study:

- Benet-Pages, A. et al. An FGF23 missense mutation causes familial tumoral calcinosis with hyperphosphatemia. Hum. Mol. Genet. 14, 385-390 (2005).

The author apologizes for the error.@ 2006 Nature Publishing Group 